\title{
Novel Monoclonal Antibodies Against Mouse C1q: Characterisation and Development of a Quantitative ELISA for Mouse C1q
}

\author{
Robert A. J. Byrne ${ }^{1,2} \cdot$ Megan Torvell $^{1,2} \cdot$ Nikoleta Daskoulidou $^{1,2} \cdot$ Dina Fathalla $^{1,2} \cdot$ Eirini Kokkali $^{3}$. \\ Sarah M. Carpanini ${ }^{1,2} \cdot$ B. Paul Morgan ${ }^{1,2}$ (D)
}

Received: 5 January 2021 / Accepted: 30 April 2021 / Published online: 18 May 2021

(c) The Author(s) 2021

\begin{abstract}
Recent studies have identified roles for complement in synaptic pruning, both physiological during development and pathological in Alzheimer's disease (AD). These reports suggest that C1q initiates complement activation on synapses and C3 fragments then tag them for removal by microglia. There is an urgent need to characterise these processes in rodent AD models; this requires the development of reagents and methods for detection and quantification of rodent $\mathrm{C} 1 \mathrm{q}$ in fluids and pathological tissues. These will enable better evaluation of the role of $\mathrm{C} 1 \mathrm{q}$ in disease and its value as disease biomarker. We describe the generation in $\mathrm{C} 1 \mathrm{q}$-deficient mice of novel monoclonal antibodies against mouse and rat $\mathrm{C} 1 \mathrm{q}$ that enabled development of a sensitive, specific, and quantitative ELISA for mouse and rat C1q capable of measuring C1q in biological fluids and tissue extracts. Serum C1q levels were measured in wild-type (WT), C1q knockout (KO), C3 KO, C7 KO, Crry $\mathrm{KO}$, and $3 \mathrm{xTg}$ and $\mathrm{APP} \mathrm{PL}^{\mathrm{NL}-\mathrm{F}} \mathrm{AD}$ model mice through ageing. C1q levels significantly decreased in WT, APP ${ }^{\mathrm{NL}-\mathrm{G}-\mathrm{F}}$, and $\mathrm{C} 7 \mathrm{KO}$ mice with ageing. C1q levels were reduced in APP ${ }^{\mathrm{NL}-\mathrm{G}-\mathrm{F}}$ compared to WT at all ages and in $3 \times \mathrm{Tg}$ at 12 months; $C 3$ $\mathrm{KO}$ and $C 7 \mathrm{KO}$, but not Crry KO mice, also demonstrated significantly lower C1q levels compared to matched WT. In brain homogenates, C1q levels increased with age in both WT and APP ${ }^{N L-G-F}$ mice. This robust and adaptable assay for quantification of mouse and rat $\mathrm{C} 1 \mathrm{q}$ provides a vital tool for investigating the expression of $\mathrm{C} 1 \mathrm{q}$ in rodent models of $\mathrm{AD}$ and other complement-driven pathologies.
\end{abstract}

Keywords Complement $\cdot$ C1q $\cdot$ ELISA $\cdot$ Mouse $\cdot$ Alzheimer's

\section{Introduction}

Alzheimer's disease $(\mathrm{AD})$ is a severe neurodegenerative disorder characterised by amyloid- $\beta$ (A $\beta$ ) plaques, neurofibrillary tangles of hyperphosphorylated tau, neuroinflammation, synaptic loss, and cognitive decline. Multiple lines of evidence, genetic and experimental, have implicated the complement system in the aetiology of AD. Genome-wide association

B. Paul Morgan

morganbp@ cardiff.ac.uk

1 UK Dementia Research Institute Cardiff, Hadyn Ellis Building, Cardiff University, Maindy Road, Cardiff CF244HQ, UK

2 Division of Infection and Immunity and Systems Immunity Research Institute, School of Medicine, Cardiff University, Hadyn Ellis Building, Heath Park, Cardiff CF144XN, UK

3 School of Optometry and Visual Sciences, Cardiff University, Maindy Road, Cardiff CF244HQ, UK studies (GWAS) have repeatedly associated single nucleotide polymorphisms (SNPs) in genes encoding complement regulators clusterin $(C L U)$ and complement receptor $1(C R I)$ with risk of late-onset AD [1-4]. Biomarker studies have identified altered levels of complement proteins and activation products in plasma and/or cerebrospinal fluid (CSF) that distinguish $\mathrm{AD}$ patients from controls and predict progression from mild cognitive impairment (MCI) to AD [5-9]. Microarray studies identified upregulation of numerous complement genes in AD patients versus age-matched controls [10]. Immunohistochemical analysis of post-mortem AD brains identified deposition of complement proteins and activation products, including $\mathrm{C} 1 \mathrm{q}$, $\mathrm{C} 3$, and $\mathrm{C} 4$, in and around plaques and tangles [11-13]. Furthermore, deletion of $\mathrm{C} 3$ or suppression of $\mathrm{C} 3$ activation in multiple $\mathrm{AD}$ mouse models increased amyloid burden, indicating that complement is involved in amyloid clearance [14-16].

The complement system is the innate immune system's primary defence against invading pathogens. In excess of 30 soluble and membrane-bound proteins, three distinct 
pathways coordinate to promote inflammation and destruction of pathogens. The classical pathway of complement activation is initiated when the circulating $\mathrm{C} 1$ complex binds to target surfaces via its $\mathrm{C} 1 \mathrm{q}$ subunit, a heterohexameric defence collagen that recognises immunoglobulin $\mathrm{Fc}$ domains [17]. The other $\mathrm{C} 1$ components $\mathrm{C} 1 \mathrm{r}$ and $\mathrm{C} 1 \mathrm{~s}$ associate with the collagen stalks of $\mathrm{Clq}$, the latter catalysing proteolysis of $\mathrm{C} 4$ and $\mathrm{C} 2$ to form the classical pathway $\mathrm{C} 3$ convertase [18]; this then cleaves the central complement component $\mathrm{C} 3$ into $\mathrm{C} 3 \mathrm{a}$ and $\mathrm{C} 3 \mathrm{~b}$ with multiple downstream consequences including opsonisation for phagocytosis, generation of the inflammatory mediator $\mathrm{C} 5 \mathrm{a}$, and formation of the membrane attack complex (MAC) [19-21].

Previous studies have highlighted a critical role for the classical complement cascade in physiological synaptic pruning during development. $\mathrm{C} 1 \mathrm{q}$ and $\mathrm{C} 3$ fragments $(\mathrm{C} 3 \mathrm{~b} /$ iC3b) localise to and tag specific synapses for removal in the developing rodent visual system and substantial synaptic pruning defects were demonstrated in $\mathrm{Clq}$ knockout (KO), $C 3 \mathrm{KO}$, and $C 4 \mathrm{KO}$ mice [22-24]. It is established that microglia are responsible for phagocytosis of synapses during developmental pruning, a process that involves interaction of complement receptor 3 (CR3; CD11b/CD18) expressed on the surface of microglia and its ligand $\mathrm{iC} 3 \mathrm{~b}$ on target synapses $[25,26]$.

Synaptic elimination also occurs pathologically, and is an early event in the pathogenesis of $\mathrm{AD}$, occurring up to 20 years prior to the onset of cognitive dysfunction [27]. Studies in AD rodent models have implicated the classical pathway in pathological synaptic loss; C1q is deposited on synapses destined for elimination, and synaptic elimination is reduced or abolished by either $C l q$ deletion or blocking of C1q with inhibitory antibodies in both amyloid and tau models [28, 29]. Microglia from CR3 KO mice displayed impaired synaptic engulfment triggered by local administration of oligomeric $A B$ [28]. Pathological synaptic pruning driven by complement is also reported in multiple sclerosis (MS) $[30,31]$ and in schizophrenia, where dysregulated $C 4$ expression contributes to abnormal synaptic pruning [24, 32, 33].

While the precise mechanism of synaptic loss in AD remains conjecture, the prevailing hypothesis is that the developmental synaptic pruning process is reactivated and becomes dysregulated, resulting in inappropriate classical pathway activation and microglial phagocytosis of complement-opsonised synapses; hence, there is a pressing requirement for reliable and reproducible methods for measuring expression of $\mathrm{C} 1 \mathrm{q}$ and other classical pathway components in fluids and pathological tissues in models and man. We have generated a panel of monoclonal antibodies against rodent $\mathrm{Clq}$ and developed an enzyme-linked immunosorbent assay (ELISA) that allows specific and quantitative measurement of mouse and rat $\mathrm{Clq}$ protein levels in serum and in brain extracts. We demonstrate that the ELISA identifies age-related changes in $\mathrm{Clq}$ concentration and differences in Clq levels between wild-type (WT) mice, complement KO mice and the $\mathrm{APP}^{\mathrm{NL}-\mathrm{G}-\mathrm{F}}$ and $3 \times \mathrm{XTg}$ mouse models of $\mathrm{AD}$.

\section{Materials and Methods}

Reagents and chemicals were purchased from Thermo Fisher Scientific (Paisley, UK) unless stated otherwise. Composition of phosphate-buffered saline (PBS) is $137 \mathrm{mM} \mathrm{NaCl}$, $2.7 \mathrm{mM} \mathrm{KCl}, 10 \mathrm{mM} \mathrm{Na} 2 \mathrm{HPO}_{4}, 1.8 \mathrm{mM} \mathrm{KH}_{2} \mathrm{PO}_{4}, \mathrm{pH}$ 7.4. All dialysis was performed overnight at $4{ }^{\circ} \mathrm{C}$ with $12-14$ $\mathrm{kDa}$ cut-off dialysis tubing (Medicell, London, UK). All cells were cultured at $37{ }^{\circ} \mathrm{C}$ in $5 \% \mathrm{CO}_{2}$. All protein stain and Western blot images were captured using the G:BOX Chemi XX6 (Syngene, Cambridge, UK).

\section{Animals}

All procedures complied with UK Animals Scientific Procedures Act 1986 and local regulations. All animals were group-housed in environmentally enriched cages, under standard pathogen-free conditions, with a 12-h light/dark cycle, and access to food and water ad libitum. C57BL/6 (WT; Harlan, Bicester, UK), Clq KO [34], C3 KO [35], C7 KO (Jackson ImmunoResearch), Crry KO [36], APP ${ }^{\text {NL-G-F }}$ [37], and 3xTg [38] mice have been described elsewhere. With the exception of the $3 \times \mathrm{Tg}$ line which is on a mixed background, all of the mouse lines were on the C57BL/6 background and all had been back-crossed onto in-house WT mice; all were maintained in the same room in the facility at the same level of containment.

All mice were humanely euthanised by increasing $\mathrm{CO}_{2}$ concentration, death was confirmed by palpation, and whole blood was collected by transcardial puncture. WT and $\mathrm{APP}^{\mathrm{NL}-\mathrm{G}-\mathrm{F}}$ mice were perfused with cold PBS; brains were removed, and snap-frozen. Blood samples were taken from 3-month-old male Brown Norway rats (Envigo, Bicester, UK) by tail tipping under anaesthesia. Collected mouse and rat blood was allowed to clot at room temperature for $10 \mathrm{~min}$, placed on ice for $1 \mathrm{~h}$, then centrifuged; serum was removed and immediately stored in aliquots at $-80{ }^{\circ} \mathrm{C}$.

Mouse brain homogenates were obtained using standard methods. In brief, frozen mouse brains (one hemisphere) were homogenised in a Dounce glass homogeniser in $1 \mathrm{ml}$ of $5 \mathrm{mM} \mathrm{KCl}, 1 \mathrm{mM} \mathrm{MgCl} 2,25 \mathrm{mM}$ HEPES, $120 \mathrm{mM} \mathrm{NaCl}$, and $2 \mathrm{mM} \mathrm{CaCl}_{2}$ (pH 7.5), supplemented with complete mini EDTA-free protease inhibitors (Roche, Welwyn Garden City, UK), and phosphatase inhibitor cocktail V (Millipore, Watford, UK). Homogenates were passed through $80-\mu \mathrm{m}$ nylon filters (Millipore). Samples were lysed on ice in RIPA buffer (Sigma-Aldrich, Gillingham, UK) containing protease 
inhibitors. The resultant lysate was centrifuged at $17,000 \times g$ for $10 \mathrm{~min}$ at $4{ }^{\circ} \mathrm{C}$ and supernatant collected. Total protein concentration was measured using the Pierce BCA protein assay kit.

\section{Isolation of Mouse C1q from Mouse Serum}

C1q was isolated from mouse serum via a three-step protocol on an ÄKTA pure chromatography system (GE Healthcare, Amersham, UK). Elements of the protocol were derived from published methods $[39,40]$. Sterile mouse serum (TCS Biosciences, Claydon, UK) was $0.22-\mu \mathrm{m}$-filtered and diluted $1: 1$ in binding buffer $(20 \mathrm{mM}$ Tris, $120 \mathrm{mM} \mathrm{NaCl}, 20 \mathrm{mM}$ EDTA, $\mathrm{pH}$ 7.0) to dissociate $\mathrm{C} 1$ complexes. Human IgG (10 mg) was immobilised on a 5-ml HiTrap NHS-Activated HP column (GE Healthcare; manufacturer's protocol); rabbit anti-human IgG antiserum was passed over this column to saturate binding sites. The column was washed and equilibrated with 5 column volumes (CV) of binding buffer. Filtered mouse serum was applied to the column, the column was washed, and bound C1q was eluted with $3 \mathrm{CV}$ of elution buffer $(50 \mathrm{mM}$ Tris, $1 \mathrm{M} \mathrm{NaCl}$, $20 \mathrm{mM}$ EDTA, $\mathrm{pH}$ 10). In order to remove contaminating mouse immunoglobulins, the eluate was applied to a $5-\mathrm{ml}$ HiTrap Protein G HP column (GE Healthcare; manufacturer's instructions), the flow-through collected, dialysed into cation exchange binding buffer (20 mM HEPES, $60 \mathrm{mM}$ $\mathrm{NaCl}, 10 \mathrm{mM}$ EDTA, $\mathrm{pH}$ 7.8), and applied to a 5-ml HiTrap SP HP column (GE Healthcare) equilibrated with $5 \mathrm{CV}$ of cation exchange binding buffer. Proteins were eluted with an increasing salt gradient in cation exchange elution buffer (to $700 \mathrm{mM} \mathrm{NaCl}$ ) over $20 \mathrm{CV}$. Fractions containing eluted protein were dialysed into $50 \mathrm{mM} \mathrm{NaH} \mathrm{PO}_{4}$ and $100 \mathrm{mM}$ $\mathrm{NaCl}$ (pH 7.4), and concentrated to $0.5 \mathrm{ml}$ using a $30-\mathrm{kDa}$ Vivaspin 6 centrifugal concentrator (Sartorius, Epsom, UK); concentration was measured using Bradford reagent according to the manufacturer's protocol (Sigma-Aldrich) and pure C1q-containing fractions identified by SDS-PAGE on inhouse $12.5 \%$ tris-glycine gels in the presence and absence of $\beta$-mercaptoethanol and stained with Coomassie $(0.25 \%$ $(w / v)$ Coomassie Brilliant Blue R-250, 40\% ( $v / v)$ methanol, $10 \%(\mathrm{v} / \mathrm{v})$ acetic acid).

The novel anti-C1q monoclonal antibodies (mAb) were also used to affinity-purify mouse $\mathrm{C} 1 \mathrm{q}$ in a single step. The $\mathrm{mAb}(3 \mathrm{mg}$ ) was conjugated to a 1-ml HiTrap NHS-activated HP column (GE Healthcare; manufacturer's protocol), pooled mouse serum was $0.22-\mu \mathrm{m}$-filtered and diluted $1: 1$ in binding buffer ( $10 \mathrm{mM}$ Tris, $150 \mathrm{mM} \mathrm{NaCl}, 20 \mathrm{mM}$ EDTA, $\mathrm{pH}$ 7.4). The mAb column was equilibrated with $5 \mathrm{CV}$ of binding buffer. Filtered mouse serum was applied to the column, the column was washed in binding buffer, and bound C1q was eluted with $3 \mathrm{CV}$ of elution buffer (100 mM glycine, 20 mM EDTA, pH 3). C1q-containing fractions were identified, dialysed, concentrated, quantified, and examined via SDS-PAGE as described above.

\section{Immunisation, Generation, and Isolation of Hybridoma}

$C l q$ KO mice (8-16 weeks of age) were immunised subcutaneously with 50- $\mu \mathrm{g}$ mouse C1q in complete Freund's adjuvant, boosted after 4 weeks with $50-\mu \mathrm{g}$ mouse $\mathrm{Clq}$ in incomplete Freund's adjuvant and then repeat boosted 1 week later. A week after the second boost, mice were tail-bled, serumharvested, and screened for immunoreactivity against mouse C1q via direct ELISA as described below. Mice with the strongest immune response then received an intra-peritoneal boost of $50 \mu \mathrm{g} \mathrm{C1q}$ in PBS and were humanely sacrificed 2 days later, and spleens were removed. Splenocytes were extracted and fused with SP2/0-Ag 14 mouse myeloma cells (European Collection of Animal Cell Cultures, Salisbury, UK) using an established protocol [41].

Cells from the fusion were grown in RPMI 1640 medium containing $2 \%$ penicillin/streptomycin, $2 \mathrm{mM}$ glutamine, $1 \mathrm{mM}$ sodium pyruvate, and $15 \%$ foetal bovine serum (FBS), supplemented with HAT (Gibco, Paisley, UK) to select hybridomas, in 96-well plates (10 plates per fusion) with $C l q \mathrm{KO}$ mouse peritoneal macrophages as feeder cells. After 14 days, medium was harvested from each well and screened for C1q immunoreactivity via direct ELISA as described below. Positive clones were sub-cloned three times by limiting dilution to ensure monoclonality, and ELISA was used for screening at each cloning to verify C1q specificity. Positive monoclonal hybridomas were then isotyped using an IsoStrip ${ }^{\mathrm{TM}}$ Mouse Monoclonal Antibody Isotyping Kit (Roche) and cultured in CELLine ${ }^{\mathrm{TM}} 1000$ bioreactor flasks (VWR, Lutterworth, UK) with RPMI 1640 medium containing $2 \%$ penicillin/streptomycin, $2 \mathrm{mM}$ glutamine, $1 \mathrm{mM}$ sodium pyruvate, and $10 \%$ ultra-low IgG FBS (Gibco). Bioreactor flasks were harvested every 7-10 days. IgG $\mathrm{mAb}$ were purified using a 5-ml HiTrap Protein G HP column (GE Healthcare; manufacturer's instructions); IgM mAb were purified using a 1-ml HiTrap Protein L column (GE Healthcare; manufacturer's instructions). All mAb were dialysed into PBS. Selected $\mathrm{mAb}$ were conjugated to biotin using the EZ-Link ${ }^{\mathrm{TM}}$ Sulfo-NHS-LC-Biotin reagent (SigmaAldrich; manufacturer's protocols).

\section{Screening for Antibodies Specific to Mouse C1q}

Pure mouse $\mathrm{C} 1 \mathrm{q}$ was diluted to $0.5 \mu \mathrm{g} / \mathrm{ml}$ in carbonate buffer (100 mM NaHCO $3,100 \mathrm{mM} \mathrm{Na}_{2} \mathrm{CO}_{3}$, pH 9.6), dispensed $\left(50 \mu \mathrm{l} /\right.$ well) into Nunc MaxiSorp ${ }^{\mathrm{TM}}$ flat-bottom 96-well plates (Invitrogen, Paisley, UK), and incubated overnight at $4{ }^{\circ} \mathrm{C}$. Wells were blocked with $2 \%(w / v)$ bovine serum albumin (BSA) in PBS-T $\left(100 \mu \mathrm{l} /\right.$ well) for $1 \mathrm{~h}$ at $37{ }^{\circ} \mathrm{C}$, 
washed twice with PBS-T, and either serum from immunised mice (diluted 1:100 in $0.2 \%$ BSA-PBS-T) or neat hybridoma supernatant $(50 \mu \mathrm{l} /$ well $)$ added and incubated for $90 \mathrm{~min}$ at $37{ }^{\circ} \mathrm{C}$. Wells were washed again with PBS-T and then incubated with a 1:1000 dilution $(50 \mu \mathrm{l} /$ well $)$ of peroxidaseconjugated goat anti-mouse $\operatorname{IgG}(\mathrm{H}+\mathrm{L})$ secondary antibody (Jackson ImmunoResearch) for $30 \mathrm{~min}$ at $37^{\circ} \mathrm{C}$. Following two final washes, plates were developed using O-phenylenediamine dihydrochloride (SIGMAFAST ${ }^{\mathrm{TM}}$ OPD, SigmaAldrich). Absorbance was measured at $492 \mathrm{~nm}$ with a FLUOstar ${ }^{\mathrm{TM}}$ Omega Microplate Reader (BMG LABTECH).

\section{ELISA Characterisation of Novel mAb}

Anti-C1q mAb were diluted to $5 \mu \mathrm{g} / \mathrm{ml}$ in carbonate buffer and coated onto Nunc MaxiSorp ${ }^{\mathrm{TM}}$ flat-bottom 96-well plates $(50 \mu \mathrm{l} /$ well $)$ for $1 \mathrm{~h}$ at $37^{\circ} \mathrm{C}$. Blocking and washing was performed as described above. Mouse (WT and $\mathrm{Clq}$ $\mathrm{KO})$, rat, and human sera were loaded in a dilution series from 1 to $0.001 \%$ and incubated at $37^{\circ} \mathrm{C}$ for $2 \mathrm{~h}$. Bound $\mathrm{C} 1 \mathrm{q}$ was detected using rabbit anti-human $\mathrm{Clq}$ polyclonal antibody ( $2 \mu \mathrm{g} / \mathrm{ml}$; in-house) and peroxidase-conjugated donkey anti-rabbit IgG secondary antibody (1:5000; Jackson ImmunoResearch, West Grove, PA, USA). OPD development was performed as detailed above.

\section{Western Blotting}

Pure mouse $\mathrm{C} 1 \mathrm{q}(1 \mu \mathrm{g})$ was run on in-house $12.5 \%$ tris-glycine gels in the presence and absence of $\beta$-mercaptoethanol, then transferred onto nitrocellulose $0.45-\mu \mathrm{m}$ membrane (GE Healthcare) using a Mini Blot Module (Invitrogen). Membranes were blocked for $1 \mathrm{~h}$ at room temperature with $5 \%(w / v)$ BSA in PBS-T, incubated with mouse anti-C1q antiserum (1:500) or anti-C1q mAb $(2 \mu \mathrm{g} / \mathrm{ml})$ overnight at $4{ }^{\circ} \mathrm{C}$ and developed using peroxidase-conjugated donkey anti-mouse $\operatorname{IgG}(\mathrm{H}+\mathrm{L})$ secondary antibody (1:5000; Jackson ImmunoResearch) followed by ECL Western blotting detection reagent (GE Healthcare).

To validate the ELISA, pure mouse C1q (200 ng) and sera (diluted 1:10 in PBS, $10 \mu$ loaded) from C1q KO, WT, and $\mathrm{APP}{ }^{\mathrm{NL}-\mathrm{G}-\mathrm{F}}$ mice ( 3 and 12 months) were analysed under reducing conditions as described above. Membranes were stained with Ponceau $\mathrm{S}$ immediately after transfer according to the manufacturer's instructions (Sigma-Aldrich). Following blocking, membranes were incubated with rabbit anti$\mathrm{Clq} \mathrm{mAb}(2 \mu \mathrm{g} / \mathrm{ml}$; Abcam, Cambridge, UK) overnight at $4{ }^{\circ} \mathrm{C}$ and developed using peroxidase-conjugated donkey anti-rabbit $\operatorname{IgG}(\mathrm{H}+\mathrm{L})$ secondary antibody (1:5000; Jackson ImmunoResearch). Densitometry was performed using GeneTools (Syngene).

\section{Haemolytic Assays}

Sheep erythrocytes were isolated from blood (TCS Biosciences) and antibody sensitized as described [42]. For assays involving mouse serum, sensitised sheep erythrocytes were additionally sensitised with $20 \mu \mathrm{g} / \mathrm{ml}$ mouse anti-rabbit $\mathrm{IgG}$ (Invitrogen). Characterisation of novel $\mathrm{mAb}$ in human, rat, and mouse haemolytic assays was performed according to published methods [43]. To assess the function of immunoaffinity-purified mouse $\mathrm{C} 1 \mathrm{q}$, a titration of purified protein $(25>0 \mu \mathrm{g} / \mathrm{ml})$ was added to $25 \% \mathrm{Cl} q \mathrm{KO}$ mouse serum and then tested in haemolysis assays as above.

\section{Development of a Sandwich ELISA for Quantification of Mouse C1q}

The anti-C1q mAb selected for capture was diluted to $5 \mu \mathrm{g} /$ $\mathrm{ml}$ in carbonate buffer and coated onto Nunc MaxiSorp ${ }^{\mathrm{TM}}$ flat-bottom 96-well plates $(50 \mu \mathrm{l} /$ well $)$ for $1 \mathrm{~h}$ at $37^{\circ} \mathrm{C}$. Blocking and washing were performed as described above. Pure C1q standards in a dilution series from $2 \mu \mathrm{g} / \mathrm{ml}>2 \mathrm{ng} /$ $\mathrm{ml}$ were loaded in duplicate to generate a standard curve. To measure levels in serum (mouse and rat) and mouse brain homogenate, samples were analysed in triplicate $(50 \mu \mathrm{l} /$ well $)$ at dilutions of 1:800 for serum and $0.5 \mathrm{mg} / \mathrm{ml}$ total protein for brain homogenates, respectively. Inter-assay controls were included on all plates. All samples and standards were incubated for $2 \mathrm{~h}$ at $37^{\circ} \mathrm{C}$ then washed twice with PBS$\mathrm{T}$. The anti-C1q mAb selected for detection (biotinylated) was diluted in $0.2 \%(w / v)$ BSA-PBS-T $(2 \mu \mathrm{g} / \mathrm{ml}, 50 \mu \mathrm{l} / \mathrm{well})$, added, and incubated for $1 \mathrm{~h}$ at $37^{\circ} \mathrm{C}$. After washing, wells were incubated $\left(1 \mathrm{~h}, 37^{\circ} \mathrm{C}\right)$ with streptavidin-HRP $(1: 200$; R\&D Systems, Abingdon, UK) diluted in $0.2 \%$ (w/v) BSAPBS-T $(50 \mu \mathrm{l} /$ well). After two final washes, colour was developed using OPD and absorbance measured as above. $\mathrm{C} 1 \mathrm{q}$ concentrations in serum and brain samples were interpolated from the standard curve using Prism 5 (GraphPad, La Jolla, CA, USA).

To test assay performance, ten WT mouse serum samples (age 3 months, male $n=6$, female $n=4$ ) were analysed using the above protocol multiple times on different days and either with or without addition of $10 \mathrm{mM}$ EDTA to dissociate $\mathrm{C} 1$. To test whether the assay could detect $\mathrm{C} 1 \mathrm{q}$ in CSF, human CSF (hCSF) was supplemented with a known quantity of pure mouse $\mathrm{C} 1 \mathrm{q}$ and then measured using the assay. Spike recovery was performed by adding a known amount of pure mouse C1q to WT mouse serum prior to dilution and then measuring levels in the base and supplemented serum using the assay as above. Spike recovery was calculated as a percentage of calculated recovery relative to expected recovery. Inter- and intra-assay coefficients of variability (\%CV) were derived from the multiple measurements by standard methods [44]. 


\section{Statistical Analyses}

All statistical analyses were performed using GraphPad Prism 5. Data points that fell $1.5 \times$ the interquartile range above or below the mean were considered outliers and excluded. All data was checked for normality with the Kolmogorov-Smirnov test. The paired $t$-test was used to test for differences in the same serum samples in the presence or absence of EDTA. The unpaired $t$-test was used to test for differences in serum C1q levels between age groups of the same complement $\mathrm{KO}$ genotype, and for differences in brain C1q levels between age groups of the WT and APP ${ }^{\mathrm{NL}-\mathrm{G}-\mathrm{F}}$ genotypes. One-way analysis of variance (ANOVA) was utilised to test for differences between age groups of the WT and APP ${ }^{\text {NL-G-F }}$ genotypes, two-way ANOVA was used to test for differences between genotypes at each age. Tukey's post hoc test and the Bonferroni post hoc test were coimplemented with one-way ANOVA and two-way ANOVA, respectively. $P<0.05$ was considered significant. C1q levels are described in the results as mean \pm standard deviation.

\section{Results}

\section{Purification of Mouse C1q and Generation of $\mathrm{mAb}$}

C1q was purified from mouse serum using IgG affinity chromatography followed by cation exchange (Fig. 1A); C1q eluted from cation exchange as a double peak, the first peak containing predominantly aggregated $\mathrm{Clq}$ (Fig. 1A, B). The second peak was aggregate-free and pure on Coomassiestained SDS-PAGE (Fig. 1B). Two fusions were performed; from 2880 wells screened, six hybridoma clones producing mouse C1q-specific antibodies were identified, five of which were IgM mAb; two of the clones, 9H10 and 2F6, gave consistently higher ELISA signal during screening and were taken forward for full characterisation (Table 1). Species cross-reactivity of $9 \mathrm{H} 10 \mathrm{mAb}$ (IgG2b isotype) and 2F6 mAb (IgM isotype) was evaluated via sandwich ELISA using a polyclonal anti-human $\mathrm{C} 1 \mathrm{q}$ for detection. 9H10 crossreacted with mouse, rat, and human C1q (Fig. 1C); 2F6 was specific for mouse and rat $\mathrm{C} 1 \mathrm{q}$ only and gave no signal with human C1q (Fig. 1D). C1 inhibitory activity of 9H10 and 2F6 was assessed in haemolysis assays; 9H10 did not inhibit in any of the sera tested (Fig. 1E), while 2F6 only inhibited haemolysis in rat serum (Fig. 1F). In order to determine the $\mathrm{C} 1 \mathrm{q}$ chain specificity of the mAbs, Western blotting was performed on purified mouse $\mathrm{C} 1 \mathrm{q}$. $9 \mathrm{H} 10$ predominantly recognised the A chain of $\mathrm{C} 1 \mathrm{q}(\sim 27 \mathrm{kDa})$ under reducing and non-reducing conditions; 2F6 was very weak in westerns, suggesting that its epitope was conformation-dependent (Fig. 1G). Immunoaffinity chromatography on $9 \mathrm{H} 10$ isolated $\mathrm{C} 1 \mathrm{q}$ from mouse serum in a single step (Fig. 1H); the purified $\mathrm{C} 1 \mathrm{q}$ restored activity to $\mathrm{Clq} \mathrm{KO}$ mouse serum, demonstrating that it was fully functional (Fig. 1I).

A quantitative sandwich ELISA was developed using $9 \mathrm{H} 10 \mathrm{mAb}$ as capture and biotinylated $2 \mathrm{~F} 6 \mathrm{mAb}$ as detection. The sandwich ELISA detected C1q in both mouse and rat sera but C1q-deficient mouse serum gave no signal in the assay (Fig. 2A). The assay did not detect $\mathrm{C} 1 \mathrm{q}$ in human serum, expected as the $2 \mathrm{~F} 6 \mathrm{mAb}$ was not reactive against human $\mathrm{C} 1 \mathrm{q}$; substitution of $2 \mathrm{~F} 6$ with a polyclonal anti-C1q antibody enabled quantification of human $\mathrm{C} 1 \mathrm{q}$ (not shown). Using pure mouse $\mathrm{C} 1 \mathrm{q}$ as standard, the assay had a detection limit of $2 \mathrm{ng} / \mathrm{ml}$ and a working range of $15 \mathrm{ng} / \mathrm{ml}$ to $250 \mathrm{ng} /$ $\mathrm{ml}$ (Fig. 2B). Dissociation of the $\mathrm{C} 1$ complex with EDTA had no significant effect on detection of C1q (Fig. 2C). Spike recovery was $93 \%$ (Fig. 2D), which was within acceptable parameters [45]. As expected, human CSF gave no signal in the assay; however, pure mouse $\mathrm{C} 1 \mathrm{q}$ spiked into human $\mathrm{CSF}$ at levels similar to those reported for $\mathrm{C} 1 \mathrm{q}$ in human CSF (200-500 ng/ml) [46] was readily detected with recovery of $73 \%$ (Fig. 2E). Two mouse serum samples, one with high and one with low C1q levels, were measured in triplicate across 10 assay plates to calculate an inter-assay coefficient of variability (\%CV): for the "high" sample, mean of means $=56.40 \mu \mathrm{g} / \mathrm{ml}, \mathrm{SD}=4.19 \mu \mathrm{g} / \mathrm{ml}, \mathrm{CV}=7.44 \%$; for the "low" sample, mean of means $=34.71 \mu \mathrm{g} / \mathrm{ml}, \mathrm{SD}=4.67 \mu \mathrm{g}$ / $\mathrm{ml}, \mathrm{CV}=13.36 \%$. The overall inter-assay CV was $10.45 \%$. Sample replicates for all cohorts were used to generate an intra-assay \% CV as described [47]; the intra-assay $\mathrm{CV}$ was $6.14 \%$.

\section{Quantification of Serum C1q in WT Mice, AD Mice, and Complement KO Mice and Rats}

The concentration of C1q in serum samples from WT and $\mathrm{APP}^{\mathrm{NL}-\mathrm{G}-\mathrm{F}}$ mice aged 3, 6, 9, and 12 months was quantified using the sandwich ELISA (Table 2). In WT mice, serum $\mathrm{C} 1 \mathrm{q}$ levels progressively decreased with age and were significantly decreased at 12 months compared to 3 months (Fig. 3A). APP ${ }^{\text {NL-G-F }}$ mice showed a more pronounced decrease with age, significant at both 9 and 12 months relative to 3 months (Fig. 3B). These observations were replicated via Western blotting with a commercial $\mathrm{mAb}$ (Figs. S1A, B). Serum C1q levels were significantly decreased in APP ${ }^{\mathrm{NL}-\mathrm{G}-\mathrm{F}}$ mice compared to WT mice in all age groups (Fig. 3C); similar trends were observed at 4 and 12 months in the $3 \times \mathrm{Tg}$ AD mice compared to WT, reaching significance at 12 months (Fig. 3D). C1q levels in rat serum measured in the ELISA were $97.69 \pm 14.31 \mu \mathrm{g} /$ $\mathrm{ml}(n=11$; data not shown). In order to evaluate whether knocking out other complement components had any effect on serum C1q levels, C1q was measured in different complement $\mathrm{KO}$ mouse strains at 6 and 12 months of age (Table 2). As expected, $C l q \mathrm{KO}$ mouse sera gave 

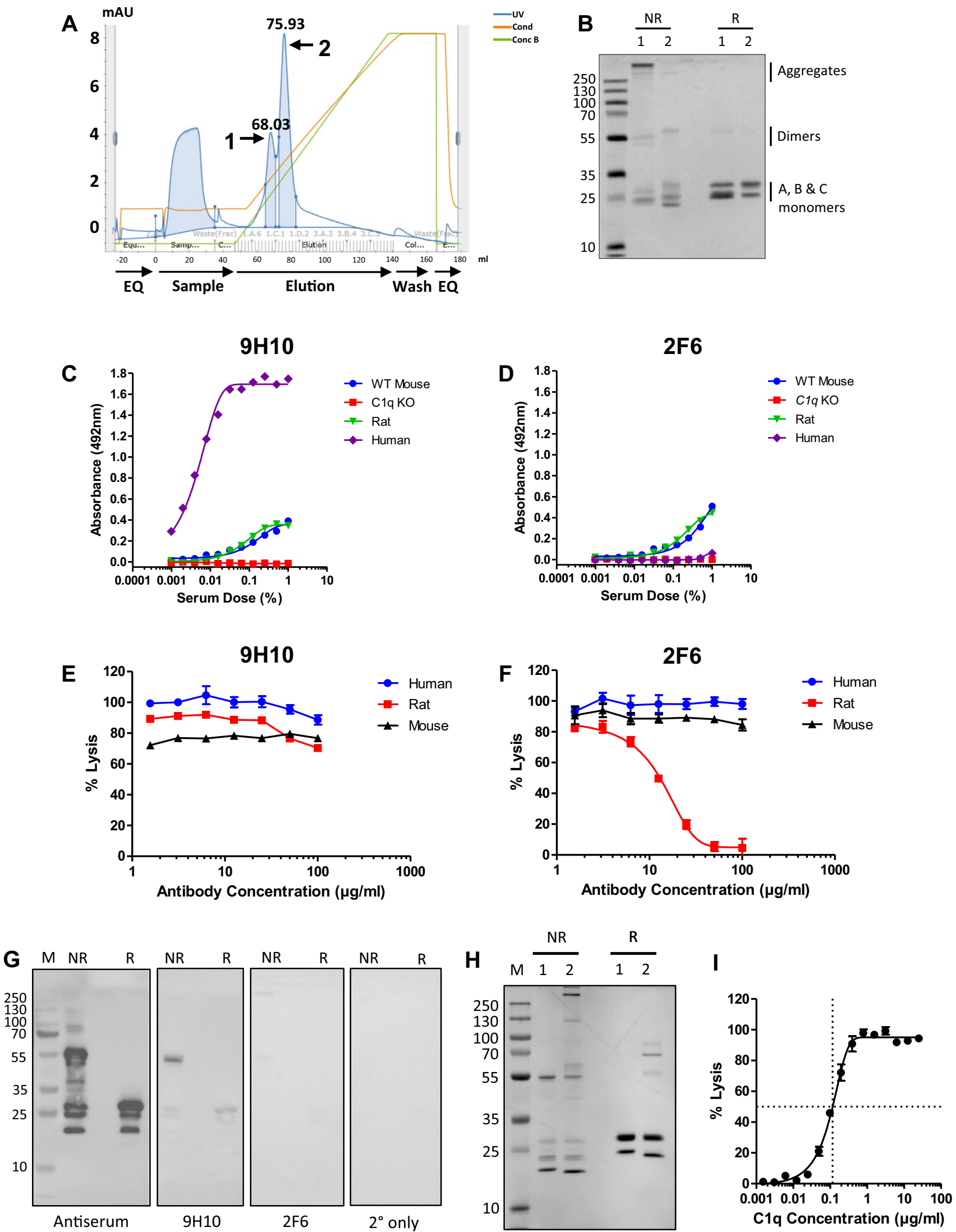
४Fig. 1 Isolation of pure mouse $\mathrm{C} 1 \mathrm{q}$ and characterisation of novel monoclonal antibodies. (A) Representative ÄKTA chromatogram from the cation exchange purification of mouse C1q showing 2 peaks. (B) SDS-PAGE of cation exchange fractions $(2.5 \mu \mathrm{g} / \mathrm{lane})$ from peak 1 and peak 2; non-reduced (NR), or reduced with $5 \%$ $\beta$-mercaptoethanol (R), proteins were stained with Coomassie blue. Peak 1 contained aggregated mouse $\mathrm{C} 1 \mathrm{q}$ that reduced to the individual $\mathrm{C} 1 \mathrm{q} \mathrm{A}, \mathrm{B}$, and $\mathrm{C}$ monomers at $31 \mathrm{kDa}, 29 \mathrm{kDa}$, and $26 \mathrm{kDa}$; peak 2 contained pure mouse $\mathrm{Clq}$ with no aggregates that reduced to C1q monomers. (C) C1q sandwich ELISA using 9H10 as capture antibody and polyclonal anti-C1q as detect showing cross-reactivity with mouse, rat, and human C1q. (D) C1q sandwich ELISA using 2F6 as capture antibody and polyclonal anti-C1q as detect showing 2F6 cross-reactivity with mouse and rat $\mathrm{C} 1 \mathrm{q}$ but not human $\mathrm{C} 1 \mathrm{q}$. (E, F) Classical pathway haemolytic assays showing that $9 \mathrm{H} 10$ had no inhibitory activity towards mouse, rat, or human C1q, while $2 \mathrm{~F} 6$ inhibited rat C1q, but not mouse or human C1q. (G) Western blot of mouse C1q. Denatured pure C1q $(1 \mu \mathrm{g} / \mathrm{lane})$ under NR and R conditions and Western blotted with mouse anti-C1q antiserum (1:500), $9 \mathrm{H} 10$, and $2 \mathrm{~F} 6(2 \mu \mathrm{g} / \mathrm{ml})$. $9 \mathrm{H} 10$ bound the A chain in denatured $\mathrm{C} 1 \mathrm{q}$ under both non-reducing and reducing conditions; staining with 2F6 was weak under both conditions. All membranes were exposed together, and for the same time, the images are unmodified from the original tif files. (H) SDS-PAGE of mouse C1q isolated via IgG affinity followed by cation exchange (1) and 9H10 immunoaffinity purification (2) under both non-reducing and reducing conditions and stained with Coomassie blue. (I) Classical pathway haemolytic assay demonstrating that titration (from $25 \mu \mathrm{g} / \mathrm{ml}$ ) of mouse $\mathrm{C} 1 \mathrm{q}$ isolated via $9 \mathrm{H} 10$ immunoaffinity restored activity to $C l q \mathrm{KO}$ serum $(25 \%)$; $116 \mathrm{ng} / \mathrm{ml}$ of mouse $\mathrm{C} 1 \mathrm{q}$ was required to restore lysis to $50 \%$

no signal in the assay (Fig. 4A). In $C 3 \mathrm{KO}$ mice, serum C1q levels were significantly lower compared to WT at 6 months but were not different between the two age points (Fig. 4B, E). Similarly, in $C 7 \mathrm{KO}$ mice, C1q levels were significantly lower compared to WT at 6 and 12 months; however, in this mouse, strain levels were significantly lower at 12 months compared to 6 months (Fig. 4D, E). In Crry KO mice, C1q levels were similar to WT at 6 and 12 months and showed a small, non-significant fall at 12 months relative to 6 months (Fig. 4C, E). There were no significant differences between genders for $\mathrm{C} 1 \mathrm{q}$ levels in any of the mouse lines (Table 2).

\section{Quantification of C1q in Brain Homogenates from WT and AD Mice}

The ELISA was used to quantify C1q levels in brain homogenates; WT and APP ${ }^{\mathrm{NL}-\mathrm{G}-\mathrm{F}}$ mice aged 3 and 12 months were analysed (Table 2); brain C1q levels, expressed relative to total protein, were significantly elevated at 12 months compared to 3 months in both WT (Fig. 5A) and APP ${ }^{\text {NL-G-F mice }}$ (Fig. 5B). When strains were compared, brain C1q levels were significantly reduced in $\mathrm{APP}^{\mathrm{NL}-\mathrm{G}-\mathrm{F}}$ mice compared to WT mice at 3 months, but not at 12 months (Fig. 5C). There were no significant differences between genders for brain C1q levels in either of the mouse lines (Table 2).

\section{Discussion}

Although long-established as hallmarks of AD and other dementias, the mechanisms of neurodegeneration and pathological synaptic loss are yet to be fully understood. There is now a substantial body of evidence that synaptic pruning, an essential developmental process, is aberrantly reactivated in the $\mathrm{AD}$ brain $[22,23]$. In $\mathrm{AD}$, it is broadly accepted that synaptic loss is the best correlate of cognitive decline [48]. Both physiological and pathological synaptic pruning are complement-dependent processes that entail activation of the classical pathway with deposition of components $\mathrm{C} 1 \mathrm{q}$ and $\mathrm{C} 3 \mathrm{~b} / \mathrm{iC} 3 \mathrm{~b}$ onto "weak" synapses, marking them for removal by microglia [28, 29]. Precisely, what $\mathrm{C} 1 \mathrm{q}$ binds on weak synapses, and what designates synapses as "weak", remains unknown. Many researchers are using rodent models to investigate the role of $\mathrm{C} 1 \mathrm{q}$ in this context; however, sensitive and reproducible methods of detecting and quantifying $\mathrm{Clq}$ in rodent biological fluids and pathological tissues are lacking. To address this need, we generated anti-C1q mAb in C1q-KO mice using pure mouse $\mathrm{C} 1 \mathrm{q}$ as immunogen, and developed a quantitative, sensitive, and specific sandwich ELISA from a non-competing pair of $\mathrm{mAb}$ that enabled measurement of $\mathrm{C} 1 \mathrm{q}$ levels in mouse and rat serum. The sandwich ELISA passed all the standard immunoassay tests of reproducibility and reliably quantified $\mathrm{C} 1 \mathrm{q}$ in rodent serum and brain tissue. Serum C1q levels measured in 3-month-old WT mice aligned with previous reports $[49,50]$.

To test the utility of the assay in experimental models, we first examined the effect of ageing on serum C1q levels in $\mathrm{WT}$ and $\mathrm{AD}$ model mice on the C57BL/6 background. We observed a progressive and significant decrease in serum C1q with age in WT mice, significant at 12 months; $\mathrm{APP}^{\mathrm{NL}-\mathrm{G}-\mathrm{F}} \mathrm{AD}$ model mice also demonstrated a progressive and significant decrease in serum $\mathrm{C} 1 \mathrm{q}$ concentrations with increasing age, more marked than in WT mice, significant at 9 and 12 months compared to 3 months. Comparison between the two strains showed decreased C1q levels in APP ${ }^{\text {NL-G-F }}$ mice compared to WT at each age (Fig. 3). We observed a similar decrease in plasma $\mathrm{C} 1 \mathrm{q}$ levels in male $3 \times \mathrm{Tg}$ AD model mice that reached significance compared to WT at 12 months despite the low sample number available for analysis. These findings contradict several reports that serum C1q levels, measured using Western blotting, a semi-quantitative and insensitive method, did not change or even increased with age in C57BL/6 mice [51, 52]. One report described a substantial increase in serum $\mathrm{C} 1 \mathrm{q}$ levels between 2 and 12 months in C57BL/6 mice via Western blotting, supported by an unspecified ELISA technique [53]. Fonseca et al., using Western blotting and densitometry, reported no significant 
Table 1 Novel $\mathrm{C} 1 \mathrm{q}$ antibodies. Six antibodies were identified via direct ELISA screening against mouse C1q. 2F6 and 9H10 consistently gave higher signals in ELISA and were taken forward for further characterisation. The remaining antibodies were discontinued and hence not tested (N/T) for cross-reactivity

\begin{tabular}{lllll}
\hline Antibody & Isotype & \multicolumn{3}{l}{ Cross-reactivity } \\
\cline { 3 - 5 } & & Mouse & Rat & Human \\
\hline $1 \mathrm{G} 1$ & IgM & + & $\mathrm{N} / \mathrm{T}$ & $\mathrm{N} / \mathrm{T}$ \\
$2 \mathrm{~F} 6$ & IgM & +++ & +++ & - \\
$7 \mathrm{~F} 3$ & IgM & ++ & $\mathrm{N} / \mathrm{T}$ & $\mathrm{N} / \mathrm{T}$ \\
$7 \mathrm{H} 2$ & IgM & + & $\mathrm{N} / \mathrm{T}$ & $\mathrm{N} / \mathrm{T}$ \\
$9 \mathrm{H} 10$ & IgG2b & +++ & +++ & +++ \\
$10 \mathrm{G} 11$ & IgM & + & $\mathrm{N} / \mathrm{T}$ & $\mathrm{N} / \mathrm{T}$ \\
\hline
\end{tabular}

differences in serum C1q levels at 5 and 10 months in the Arctic48 AD model compared to WT mice [52]. The fact that we used a sensitive and specific ELISA, incorporating two $\mathrm{mAb}$ against mouse $\mathrm{C} 1 \mathrm{q}$ and properly validated with appropriate quality control measure, gives us confidence that the findings we report in WT and AD model mice are correct. We show that our assay accurately measures both free $\mathrm{C} 1 \mathrm{q}$ and $\mathrm{C} 1 \mathrm{q}$ in the $\mathrm{C} 1$ complex, important in contexts where the proportions of free $\mathrm{C} 1 \mathrm{q}$ and $\mathrm{C} 1$ complex might vary and enabling quantification in both serum and EDTA plasma; in the latter, $\mathrm{Ca}^{2+}$ chelation disrupts the C1 complex.

Several studies report that serum C1q levels increase with age in healthy human donors $[54,55]$. In our recent AD plasma biomarker study, there was no difference in serum $\mathrm{C} 1 \mathrm{q}$ levels between aged healthy controls, and individuals with $\mathrm{MCI}$ or $\mathrm{AD}$ [8]. Others have reported that $\mathrm{C} 1 \mathrm{q}$ levels are reduced in the CSF of AD patients compared to controls and suggested that this might be an AD biomarker [56]. Of note, CSF C1q levels reported in this study were $\sim 0.2-0.4 \mu \mathrm{g} / \mathrm{ml}$, comfortably within the working range of our assay. We were unable to source mouse CSF for the study, so to support the capacity of our assay to measure C1q in CSF, we spiked mouse C1q into human CSF at a relevant dose and showed that it could be measured in the assay with good recovery. While we are not aware of published studies measuring $\mathrm{C} 1 \mathrm{q}$ levels in rodent CSF, the assay detects mouse $\mathrm{C} 1 \mathrm{q}$ in an appropriate matrix (human CSF) at the low $(\mathrm{ng} / \mathrm{ml})$ levels predicted from human data to be present in rodent CSF; these data show that the described assay offers the prospect of such studies in disease models.

Next, we explored the impact of complement gene knockouts; serum C1q was measured in $C 1 q \mathrm{KO}, C 3$ $\mathrm{KO}, C 7 \mathrm{KO}$, and Crry KO mouse models (Fig. 4). All of these lines were on the C57/BL6 background, all had been back-crossed onto the in-house C57BL/6 (WT) line, and all were maintained in the same room and under identical containment; these precautions reduce but do not eliminate risk of other genetic or environmental differences impacting the inter-line comparison. As expected, serum from $\mathrm{C} 1 \mathrm{q}$ KO mice gave no signal in the assay, confirming the specificity of the assay and the novel mAbs reported here. Serum $\mathrm{C} 1 \mathrm{q}$ levels were reduced in $C 3 \mathrm{KO}$ mice at 6 and 12 months, significantly in the former, compared with matched WT mice. Precisely, how the absence of C3 impacts C1q levels is unclear; however, collaboration between $\mathrm{C} 1 \mathrm{q}$ and $\mathrm{C} 3$ is critical to modulation of innate and adaptive immunity in mice and men [57, 58]. Absence of C3 might thus favour immune dysregulation and increased $\mathrm{C} 1 \mathrm{q}$ consumption. Crry is the dominant cell-associated C3 convertase inhibitor in rodents; deficiency of Crry causes systemic consumption of $\mathrm{C} 3$ and secondary $\mathrm{C} 3$ deficiency [36]. No differences in C1q levels were observed between WT and Crry KO mice at any age suggesting that secondary $\mathrm{C} 3$ deficiency does not have the same effect as primary $\mathrm{C} 3$ deficiency in the mice. In $C 7 \mathrm{KO}$ mice, serum $\mathrm{C} 1 \mathrm{q}$ levels were significantly reduced at 6 and 12 months compared to matched WT mice, an unexpected finding given that absence of $\mathrm{C} 7$ impacts only the terminal pathway and formation of MAC. MAC plays roles in the homeostatic clearance of apoptotic cells [58, 59]; we suggest that absence of MAC may lead to an increased burden of apoptotic cells during ageing that bind C1q, well described in lupus models, leading to reduced plasma C1q levels.

Finally, in order to demonstrate whether the assay could be used to measure levels of $\mathrm{C} 1 \mathrm{q}$ in tissue extracts, we measured the protein in mouse brain homogenate (Fig. 5). The assay performed well in brain homogenates, and we observed a significant increase in brain C1q levels at 12 months compared to 3 months in WT mice, a finding that is concordant with the literature as both C1q protein and mRNA levels have been reported to increase with age in the human and mouse brain $[10,51,60]$. We also demonstrated a significant increase in brain C1q levels in aged $\mathrm{APP}^{\mathrm{NL}-\mathrm{G}-\mathrm{F}}$ mice, almost doubling from 3 to 12 months of age. Brain C1q levels were significantly lower in APP ${ }^{\mathrm{NL}-\mathrm{G}-\mathrm{F}}$ mice relative to WT mice at 3 months, but because of the extent of increase with age, they were not significantly different at 12 months. Others have reported increased C1q expression in and around areas of pathology in the APP ${ }^{\text {NL-G-F }}$ model [61]. Our whole-brain measures would miss local changes in expression; dissection and separate analysis of key brain regions for measurement of such changes is an obvious next step. Elevated brain C1q levels at late disease stage in $\mathrm{AD}$ mouse models relative to matched WT mice have been reported in several other studies, mostly using Western blotting to semi-quantify C1q $[28,52,60-62]$. Although there is an abundance of immunohistochemical evidence for $\mathrm{C} 1 \mathrm{q}$ deposition in late-stage AD brain [63, 64], we are not aware of published studies that quantitatively measure $\mathrm{C} 1 \mathrm{q}$ protein levels in healthy and AD human brain tissue; our unpublished work suggests that 

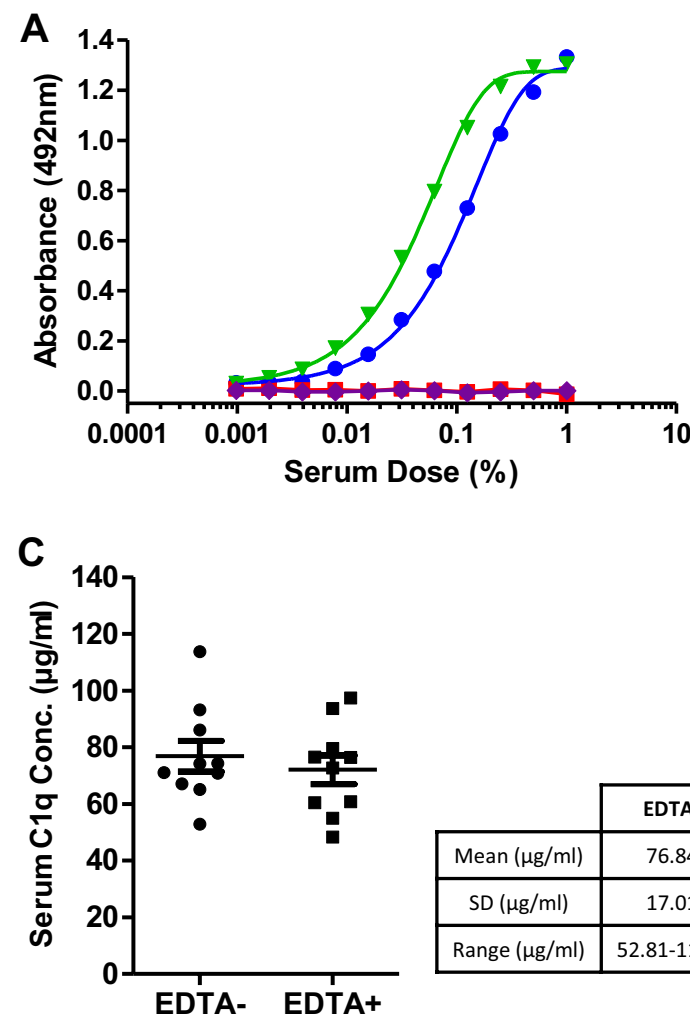

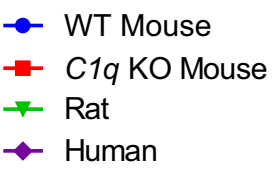

\begin{tabular}{|c|c|c|}
\cline { 2 - 3 } \multicolumn{1}{c|}{} & EDTA- & EDTA+ \\
\hline Mean $(\mu \mathrm{g} / \mathrm{ml})$ & 76.84 & 72.06 \\
\hline SD $(\mu \mathrm{g} / \mathrm{ml})$ & 17.01 & 16.06 \\
\hline Range $(\mu \mathrm{g} / \mathrm{ml})$ & $52.81-113.7$ & $48.3-97.39$ \\
\hline
\end{tabular}

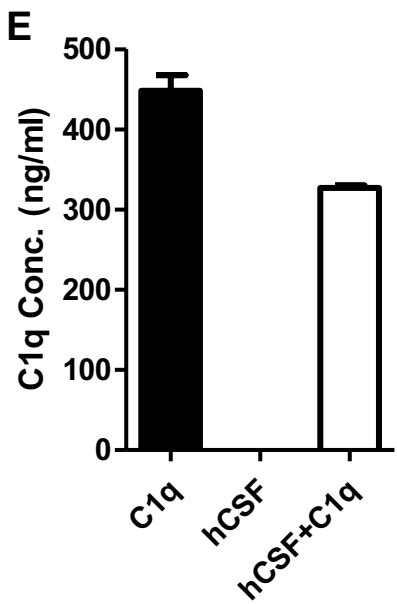

Fig. 2 Optimisation and quality testing of in-house quantitative sandwich ELISA. (A) C1q sandwich ELISA using $9 \mathrm{H} 10 \mathrm{mAb}$ as capture and biotinylated $2 \mathrm{~F} 6 \mathrm{mAb}$ as detection. Standard curves were generated by titrating WT mouse, $C l q \mathrm{KO}$ mouse, rat, and human serum from $1 \%$ serum concentration. The assay detected $\mathrm{C} 1 \mathrm{q}$ in mouse and rat but not human serum. (B) Pure C1q was used as standard in the assay; detection range was $10-500 \mathrm{ng} / \mathrm{ml}$. (C) Measurement of the same WT mouse serum samples ( 3 months, male $n=6$, female $n=4)$ in the presence or absence of $10 \mathrm{mM}$ EDTA to dissociate the

the assay described here, modified to measure human C1q, could detect and quantify $\mathrm{C} 1 \mathrm{q}$ in $\mathrm{AD}$ brain extracts.

Although the current work is focussed on AD models, complement-driven synaptic elimination is also reported
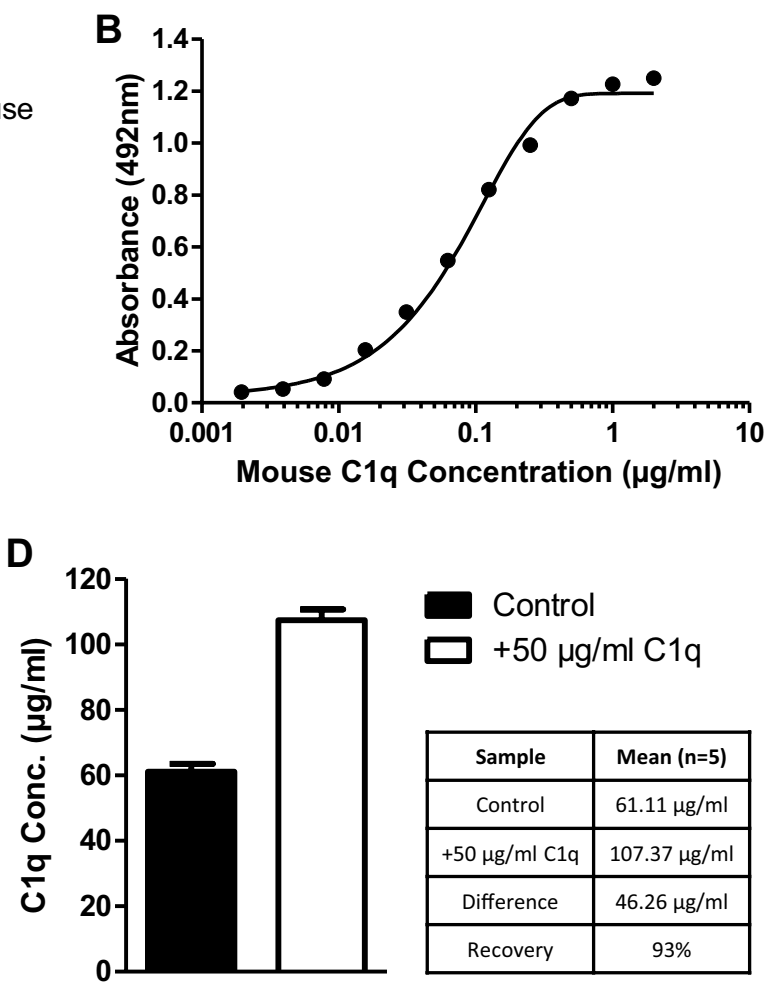

\begin{tabular}{|c|c|}
\hline Sample & Mean (n=3) \\
\hline $500 \mathrm{ng} / \mathrm{ml} \mathrm{C1q}$ & $448.26 \mathrm{ng} / \mathrm{ml}$ \\
\hline CSF $+500 \mathrm{ng} / \mathrm{ml} \mathrm{C1q}$ & $327.15 \mathrm{ng} / \mathrm{ml}$ \\
\hline Difference & $121.11 \mathrm{ng} / \mathrm{ml}$ \\
\hline Recovery & $73 \%$ \\
\hline
\end{tabular}

$\mathrm{C} 1$ complex. EDTA had no significant effect on measured C1q levels. (D) Spike recovery. Mouse C1q $(50 \mu \mathrm{g} / \mathrm{ml})$ was added into WT mouse serum samples ( 3 months, male, $n=5$ ) and C1q levels measured. Average recovery was $93 \%$. (E) C1q spiked into human CSF (hCSF). Mouse C1q (500 ng/ml) was spiked into hCSF samples $(n=3$; hCSF/C1q) or the same volume of buffer (C1q); C1q levels were measured. Unspiked hCSF was used as a control. Average recovery was $73 \%$

in other neurodegenerative disorders, including MS, and in neurodevelopmental disorders such as schizophrenia. Beyond the brain, $\mathrm{C} 1 \mathrm{q}$ is a critical factor in autoimmune and autoinflammatory diseases [65]. Hence, the 
Table 2 Sample cohorts. A list of each strain and age cohort analysed in the ELISA, including the number of animals of each gender within each cohort at 3,4,6,9, and 12 months (m). Mean serum and brain $\mathrm{C} 1 \mathrm{q}$ levels are reported in microgrammes per millilitre and nanogrammes per microgramme total brain lysate protein $( \pm s d)$, respectively. No significant differences in gender were found in any of the mouse lines (non-significant; ns). $n / a$, not applicable

\begin{tabular}{|c|c|c|c|c|c|c|}
\hline & Genotype & Age & Male & Female & $\mathrm{C} 1 \mathrm{q}($ mean $\pm \mathrm{sd})$ & $\begin{array}{l}\text { Gender } \\
\text { differ- } \\
\text { ence }\end{array}$ \\
\hline \multirow[t]{19}{*}{ Serum } & \multirow[t]{4}{*}{ WT } & $3 \mathrm{~m}$ & 6 & 4 & $72.45 \pm 15.25$ & Ns \\
\hline & & $6 \mathrm{~m}$ & 5 & 5 & $64.76 \pm 8.95$ & Ns \\
\hline & & $9 \mathrm{~m}$ & 4 & 6 & $59.91 \pm 16.11$ & Ns \\
\hline & & $12 \mathrm{~m}$ & 5 & 7 & $55.54 \pm 12.38$ & Ns \\
\hline & \multirow[t]{4}{*}{$\mathrm{APP} \mathrm{P}^{\mathrm{NL}-\mathrm{G}-\mathrm{F}}$} & $3 \mathrm{~m}$ & 5 & 5 & $56.01 \pm 16.54$ & Ns \\
\hline & & $6 \mathrm{~m}$ & 5 & 4 & $43.08 \pm 6.31$ & Ns \\
\hline & & $9 \mathrm{~m}$ & 4 & 6 & $40.42 \pm 12.98$ & Ns \\
\hline & & $12 \mathrm{~m}$ & 4 & 6 & $40.16 \pm 9.55$ & Ns \\
\hline & \multirow[t]{2}{*}{$3 x \operatorname{~Tg}$} & $4 \mathrm{~m}$ & 4 & 0 & $46.95 \pm 17.50$ & $\mathrm{n} / \mathrm{a}$ \\
\hline & & $12 \mathrm{~m}$ & 5 & 0 & $32.86 \pm 11.07$ & $\mathrm{n} / \mathrm{a}$ \\
\hline & \multirow[t]{2}{*}{ C3 KO } & $6 \mathrm{~m}$ & 3 & 4 & $39.41 \pm 7.08$ & Ns \\
\hline & & $12 \mathrm{~m}$ & 4 & 3 & $41.92 \pm 6.20$ & Ns \\
\hline & \multirow[t]{2}{*}{$C 7 \mathrm{KO}$} & $6 \mathrm{~m}$ & 5 & 4 & $49.51 \pm 15.01$ & Ns \\
\hline & & $12 \mathrm{~m}$ & 5 & 5 & $32.84 \pm 8.30$ & Ns \\
\hline & \multirow[t]{2}{*}{ Crry KO } & $6 \mathrm{~m}$ & 6 & 6 & $68.31 \pm 25.70$ & Ns \\
\hline & & $12 \mathrm{~m}$ & 5 & 4 & $56.87 \pm 16.81$ & Ns \\
\hline & \multirow[t]{2}{*}{$C 1 q \mathrm{KO}$} & $6 \mathrm{~m}$ & 6 & 5 & $\mathrm{n} / \mathrm{a}$ & $\mathrm{n} / \mathrm{a}$ \\
\hline & & $12 \mathrm{~m}$ & 4 & 4 & $\mathrm{n} / \mathrm{a}$ & $\mathrm{n} / \mathrm{a}$ \\
\hline & Rat & $3 \mathrm{~m}$ & 11 & 0 & $97.69 \pm 14.31$ & $\mathrm{n} / \mathrm{a}$ \\
\hline \multirow[t]{4}{*}{ Brain } & \multirow[t]{2}{*}{ WT } & $3 \mathrm{~m}$ & 4 & 4 & $0.285 \pm 0.039$ & ns \\
\hline & & $12 \mathrm{~m}$ & 4 & 4 & $0.353 \pm 0.043$ & ns \\
\hline & \multirow[t]{2}{*}{$A P P^{N L-G-F}$} & $3 \mathrm{~m}$ & 4 & 4 & $0.234 \pm 0.013$ & ns \\
\hline & & $12 \mathrm{~m}$ & 4 & 4 & $0.386 \pm 0.024$ & $\mathrm{~ns}$ \\
\hline
\end{tabular}

availability of a novel ELISA to reliably quantify C1q levels in rodent biological fluids and tissues may have wide application in the study of models of diverse complementdriven disorders.

Supplementary Information The online version contains supplementary material available at https://doi.org/10.1007/s12035-021-02419-5.

Acknowledgements The work was supported by the UK Dementia Research Institute. We thank Neil Evans for technical and animal support, Dr. Wioleta Zelek for help with ELISA optimisation, and Dr. Tim Hughes for access to $3 \mathrm{xTg}$ samples.

Author Contribution RB led the assay development work; BPM designed and supervised the project; all other authors contributed to aspects of the experimental work. RB, MT, and SC drafted the manuscript; BPM finalised the submission.

Funding This work was supported by a Programme Grant from the UK Dementia Research Institute, part funded by the UK Medical Research Council.

Data Availability Primary data and materials described are available on reasonable request for academic use.
Code Availability Not applicable.

\section{Declarations}

Ethics Approval No human subjects were involved in this research so informed consent is not relevant. Animals use was under the auspices of UK Home Office Licence numbers PF4167C0A and P8159A562.

Consent to Participate No human subjects were involved in this research, so consent to participate is not relevant.

Consent for Publication All authors have approved this manuscript and consented to its submission for publication.

Conflict of Interest The authors declare no competing interests.

Open Access This article is licensed under a Creative Commons Attribution 4.0 International License, which permits use, sharing, adaptation, distribution and reproduction in any medium or format, as long as you give appropriate credit to the original author(s) and the source, provide a link to the Creative Commons licence, and indicate if changes were made. The images or other third party material in this article are included in the article's Creative Commons licence, unless indicated otherwise in a credit line to the material. If material is not included in the article's Creative Commons licence and your intended use is not 
WT

A

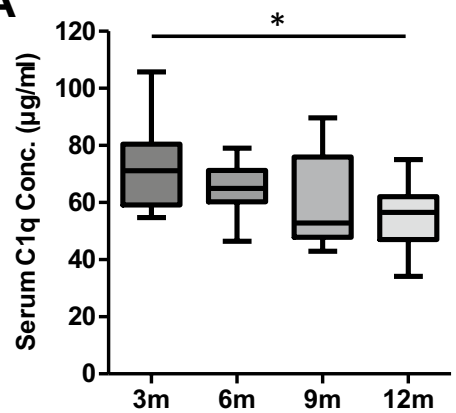

APPNL-G-F

B

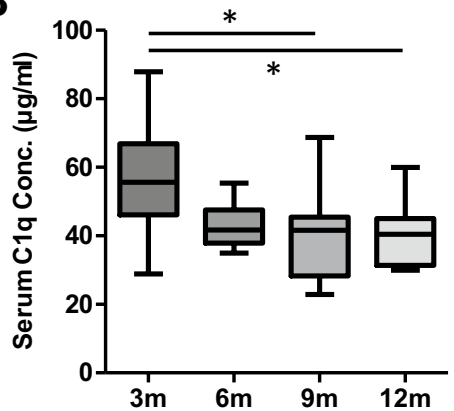

C

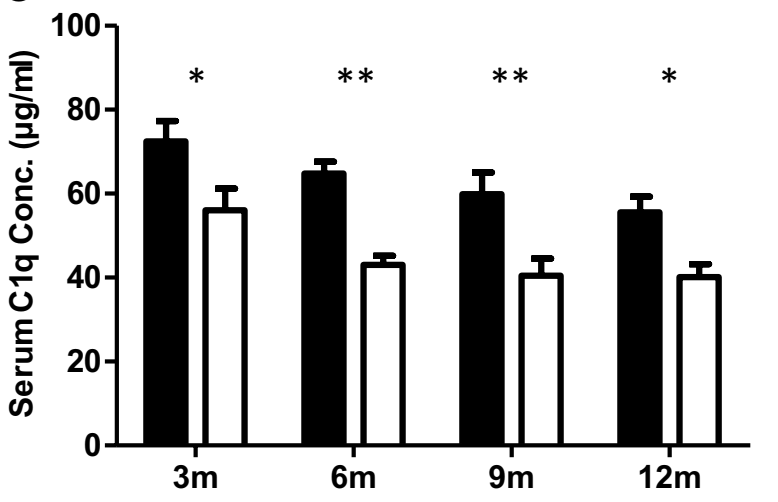

Fig. 3 Measurement of $\mathrm{C} 1 \mathrm{q}$ levels in WT and APP $\mathrm{PL}^{\text {NL-F }}$ mouse serum by quantitative sandwich ELISA. (A) Serum C1q levels measured in WT mice at 3, 6, 9, and 12 months. C1q levels were significantly decreased at 12 months compared to 3 months $(P<0.05)$. (B) Serum C1q levels measured in $\mathrm{APP}^{\mathrm{NL}-\mathrm{G}-\mathrm{F}}$ mice at 3,6 , 9, and 12 months. Serum C1q levels were significantly reduced at 9 and 12 months compared to 3 months $(P<0.05)$. (C) Serum C1q lev-

permitted by statutory regulation or exceeds the permitted use, you will need to obtain permission directly from the copyright holder. To view a copy of this licence, visit http://creativecommons.org/licenses/by/4.0/.

\section{References}

1. Harold D, Abraham R, Hollingworth P, Sims R, Gerrish A, Hamshere ML, Pahwa JS, Moskvina V et al (2009) Genome-wide association study identifies variants at CLU and PICALM associated with Alzheimer's disease. Nature Genet 41(10):1088-1093. https://doi.org/10.1038/ng.440

2. Lambert JC, Heath S, Even G, Campion D, Sleegers K, Hiltunen M, Combarros O, Zelenika D et al (2009) Genome-wide association study identifies variants at CLU and CR1 associated with Alzheimer's disease. Nature Genet 41(10):1094-1099. https:// doi.org/10.1038/ng.439

3. Lambert JC, Ibrahim-Verbaas CA, Harold D, Naj AC, Sims R, Bellenguez C, DeStafano AL, Bis JC et al (2013) Meta-analysis of 74,046 individuals identifies 11 new susceptibility loci for
WT

$A P P^{N L-G-F}$

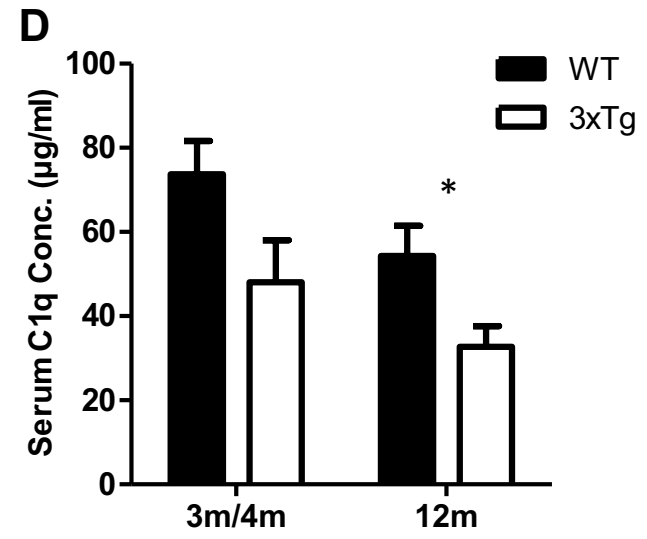

els were significantly lower in APP ${ }^{\mathrm{NL}-\mathrm{G}-\mathrm{F}}$ mice than WT mice at all ages examined $(*=P<0.05, * *=P<0.01)$. (D) $\mathrm{C} 1 \mathrm{q}$ was measured in serum from male $3 \times \mathrm{Tg}$ and WT mice at 3-4 months $(3 \mathrm{xTg}, n=4$; WT, $n=6)$ and at 12 months ( $3 \times \mathrm{Tg}, n=5 ; \mathrm{T}, n=5)$. C1q levels were lower in $3 \times$ Tg mice compared to WT at each age, significantly at 12 months (3-4 months, $p=0.078$; 12 months, $p=0.038$; $t$ test)

Alzheimer's disease. Nature Genet 45(12):1452-1458. https:// doi.org/10.1038/ng.2802

4. Kunkle BW, Grenier-Boley B, Sims R, Bis JC, Damotte V, Naj AC, Boland A, Vronskaya M et al (2019) Genetic meta-analysis of diagnosed Alzheimer's disease identifies new risk loci and implicates $A \beta$, tau, immunity and lipid processing. Nature Genet 51(3):414-430. https://doi.org/10.1038/s41588-019-0358-2

5. Hakobyan S, Harding K, Aiyaz M, Hye A, Dobson R, Baird A, Liu B, Harris CL et al (2016) Complement biomarkers as predictors of disease progression in Alzheimer's disease. $\mathrm{J} \mathrm{Alz}$ Dis 54(2):707-716. https://doi.org/10.3233/JAD-160420

6. Hu WT, Watts KD, Tailor P, Nguyen TP, Howell JC, Lee RC, Seyfried NT, Gearing M et al (2016) CSF complement 3 and factor $\mathrm{H}$ are staging biomarkers in Alzheimer's disease. Acta Neuropathol Comm 4(14). https://doi.org/10.1186/ s40478-016-0277-8

7. Morgan AR, Touchard S, O'Hagan C, Sims R, Majounie E, Escott-Price V, Jones L, Williams J et al (2017) The correlation between inflammatory biomarkers and polygenic risk score in Alzheimer's disease. J Alz Dis 56(1):25-36. https://doi.org/10. 3233/JAD-160889 

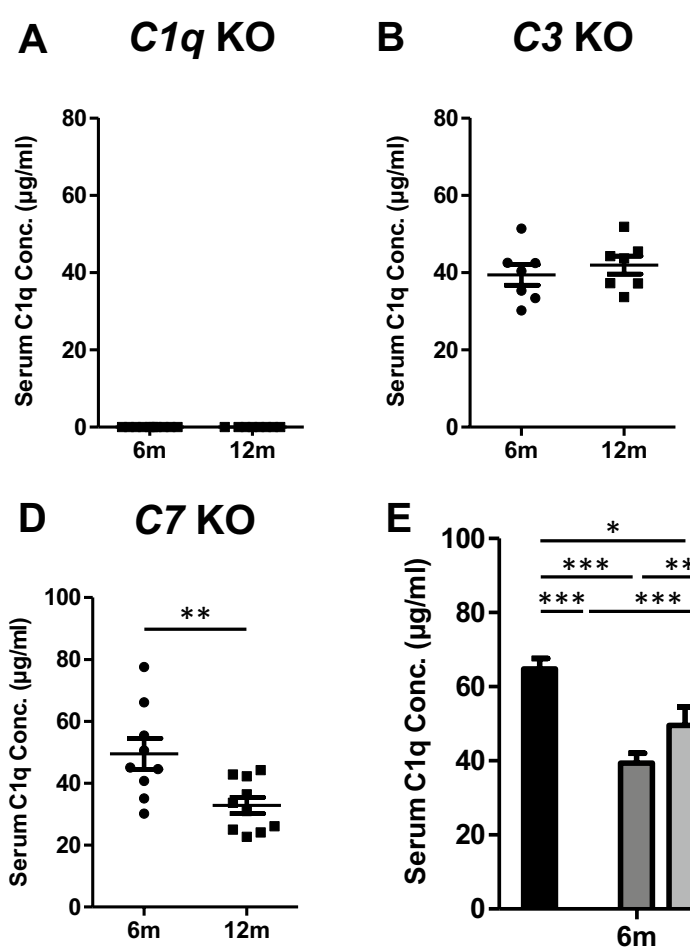

E

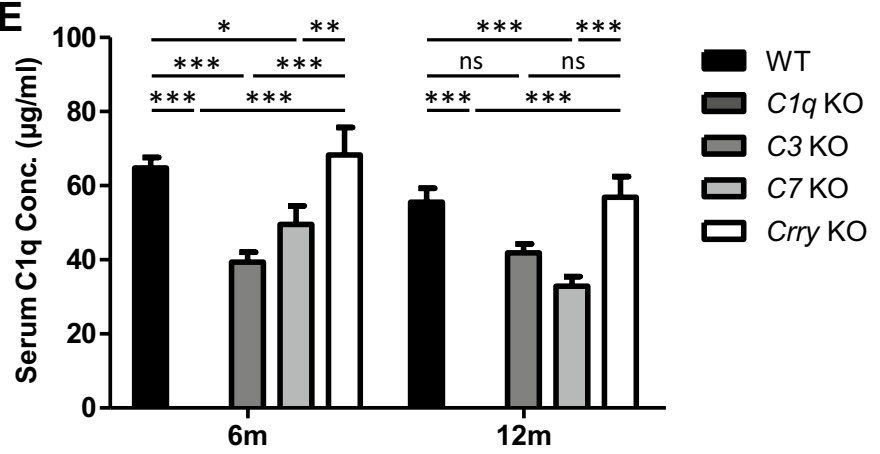

Fig. 4 Measurement of C1q levels in $C l q \mathrm{KO}, C 3 \mathrm{KO}$, Crry KO, and $C 7 \mathrm{KO}$ mouse serum by quantitative sandwich ELISA. (A) Serum $\mathrm{C} 1 \mathrm{q}$ levels were measured in $\mathrm{Clq} \mathrm{KO}$ mice; no $\mathrm{C} 1 \mathrm{q}$ was detected at 6 or 12 months. (B-C) Measurement of serum C1q levels in B C3 KO and $\mathbf{C ~ C r r y ~ K O}$ mice at 6 and 12 months of age; no significant differences in serum $\mathrm{C} 1 \mathrm{q}$ levels were observed between 6 and 12 months $(P>0.05)$. (D) Measurement of serum C1q levels in $C 7 \mathrm{KO}$ mice; a significant decrease was identified at 12 months compared to 6 months of age $(P<0.01)$. (E) Serum C1q levels in $C 3 \mathrm{KO}, C 7 \mathrm{KO}$, and $C l q \mathrm{KO}$ were significantly reduced relative to WT and Crry KO at 6 months. At 12 months, serum $\mathrm{Clq}$ was only significantly reduced in $C 7 \mathrm{KO}$ and $C l q \mathrm{KO}$ mice compared to WT and Crry $\mathrm{KO}$ mice. There were no significant differences between WT and Crry KO mice. $*=P<0.05, * *=P<0.01, * * *=P<0.001$
8. Morgan AR, Touchard S, Leckey C, O'Hagan C, Nevado-Holgado AJ, NIMA Consortium, Barkhof F, Bertram L, Blin O et al (2019) Inflammatory biomarkers in Alzheimer's disease plasma. Alz Dement 15(6):776-787. https://doi.org/10.1016/j.jalz.2019. 03.007

9. Rasmussen KL, Nordestgaard BG, Frikke-Schmidt R, Nielsen SF (2018) An updated Alzheimer hypothesis: complement C3 and risk of Alzheimer's disease-A cohort study of 95,442 individuals. Alz Dement 14(12):1589-1601. https://doi.org/ 10.1016/j.jalz.2018.07.223

10. Cribbs DH, Berchtold NC, Perreau V, Coleman PD, Rogers J, Tenner AJ, Cotman CW (2012) Extensive innate immune gene activation accompanies brain aging, increasing vulnerability to cognitive decline and neurodegeneration: a microarray study. J Neuroinflamm 9(179):1-18. https://doi.org/10.1186/ 1742-2094-9-179

11. Ishii T, Haga S (1984) Immuno-electron-microscopic localization of complements in amyloid fibrils of senile plaques. Acta Neuropathol 63(4):296-300. https://doi.org/10.1007/BF00687336

12. Rogers J, Cooper NR, Webster S, Schultz J, McGeer PL, Styren SD, Civin WH, Brachova L et al (1992) Complement activation by $\beta$-amyloid in Alzheimer disease. Proc Natl Acad Sci U S A 89(21):10016-10020. https://doi.org/10.1073/pnas.89. 21.10016

13. Veerhuis R, Van Breemen MJ, Hoozemans JM, Morbin M, Ouladhadj J, Tagliavini F, Eikelenboom P et al (2003) Amyloid $\beta$ plaque-associated proteins $\mathrm{C} 1 \mathrm{q}$ and SAP enhance the $\mathrm{A} \beta 1-42$ peptide-induced cytokine secretion by adult human microglia in vitro. Acta Neuropathol 105(2):135-144. https://doi.org/10. 1007/s00401-002-0624-7

14. Wyss-Coray T, Yan F, Lin AH, Lambris JD, Alexander JJ, Quigg RJ, Masliah E (2002) Prominent neurodegeneration and increased plaque formation in complement-inhibited Alzheimer's mice. Proc Natl Acad Sci U S A 99(16):10837-10842. https://doi.org/10. 1073/pnas.162350199

15. Maier M, Peng Y, Jiang L, Seabrook TJ, Carroll MC, Lemere CA (2008) Complement C3 deficiency leads to accelerated amyloid $\beta$ plaque deposition and neurodegeneration and modulation of the microglia/macrophage phenotype in amyloid precursor protein transgenic mice. J Neurosci 28(25):6333-6341. https://doi.org/10.1523/JNEUROSCI.0829-08.2008

16. Shi Q, Chowdhury S, Ma R, Le KX, Hong S, Caldarone BJ, Stevens B, Lemere CA (2017) Complement C3 deficiency protects against neurodegeneration in aged plaque-rich APP/PS1 mice. Science Trans Med 9(392). https://doi.org/10.1126/scitranslm ed.aaf6295

17. Reid KBM, Porter RR (1976) Subunit composition and structure of subcomponent C1q of the first component of human complement. Biochem J 155(1):19-23. https://doi.org/10.1042/bj155 0019

18. Müller-Eberhard HJ, Polley MJ, Calcott MA (1967) Formation and functional significance of a molecular complex derived from the second and the fourth component of human complement. J Exp Med 125(2):359-380 


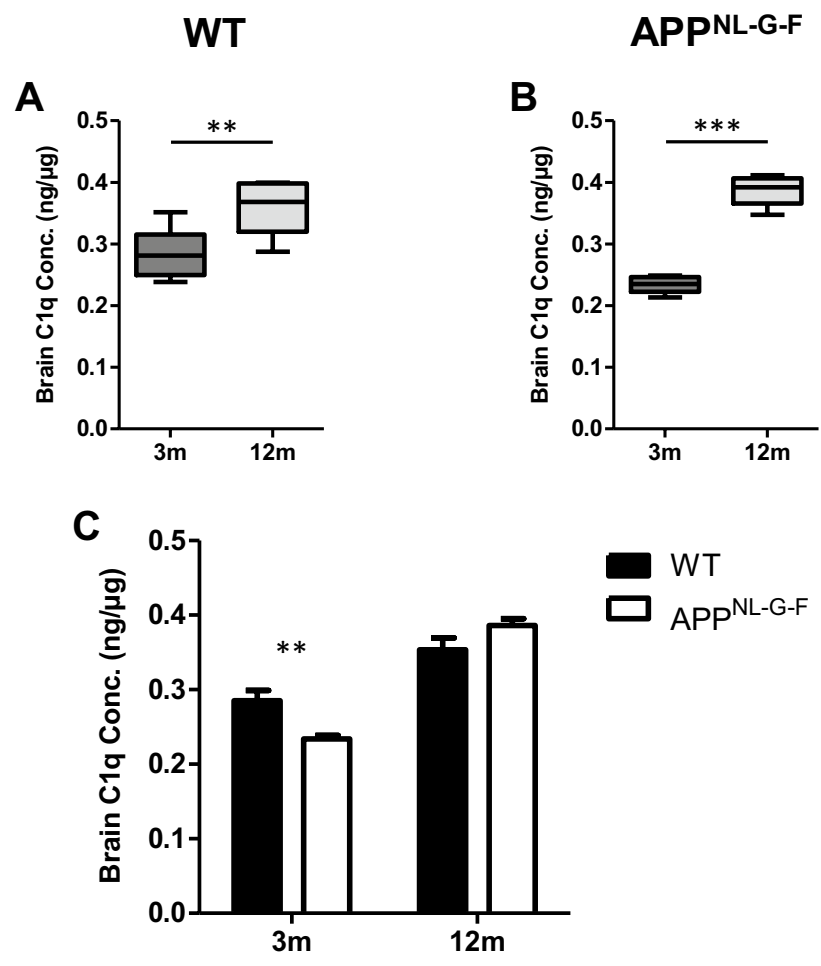

Fig. 5 Measurement of $\mathrm{C} 1 \mathrm{q}$ in WT and APP ${ }^{\text {NL-G-F }}$ mouse wholebrain lysates by quantitative sandwich ELISA. (A) C1q levels were measured in brain lysates from WT mice at 3 and 12 months and normalised to total protein in the lysate. Brain C1q levels were significantly elevated at 12 months compared to 3 months $(P<0.01)$. (B) $\mathrm{C} 1 \mathrm{q}$ levels were measured in $\mathrm{APP}^{\mathrm{NL}-\mathrm{G}-\mathrm{F}}$ mouse whole-brain lysates, normalised as above, at 3 and 12 months. Brain C1q levels were significantly higher at 12 months $(P<0.001)$. (C) Brain $\mathrm{C} 1 \mathrm{q}$ levels were significantly lower in APP ${ }^{\mathrm{NL}-\mathrm{G}-\mathrm{F}}$ mice than WT mice at 3 months $(P<0.01)$, but were not significantly different between the lines at 12 months. Units are nanogrammes of $\mathrm{C} 1 \mathrm{q}$ per microgramme of total brain protein

19. Müller-Eberhard HJ, Dalmasso A, Calcott M (1966) The reaction mechanism of beta-1C-globulin (C'3) in immune hemolysis. J Exp Med 123(1):33-54. https://doi.org/10.1084/jem.132.4. 775

20. Cochrane C, Müller-Eberhard H (1968) The derivation of two distinct anaphylatoxin activities from the third and fifth components of human complement. J Exp Med 127:371-386

21. Serna M, Giles JL, Morgan BP, Bubeck D (2016) Structural basis of complement membrane attack complex formation. Nature Comm 7:1-7. https://doi.org/10.1038/ncomms 10587

22. Stevens B, Allen NJ, Vazquez LE, Howell GR, Christopherson KS, Nouri N, Micheva KD, Mehalow AK et al (2007) The classical complement cascade mediates CNS synapse elimination. Cell 131(6):1164-1178. https://doi.org/10.1016/j.cell.2007.10.036

23. Bialas AR, Stevens B (2013) TGF- $\beta$ signaling regulates neuronal $\mathrm{C} 1 \mathrm{q}$ expression and developmental synaptic refinement. Nature Neurosci 16(12):1773-1782. https://doi.org/10.1038/ nn. 3560

24. Sekar A, Bialas AR, de Rivera H, Davis A, Hammond TR, Kamitaki N, Tooley K, Presumey J et al (2016) Schizophrenia risk from complex variation of complement component 4 . Nature 530(7589):177-183. https://doi.org/10.1038/nature16549
25. Paolicelli RC, Bolasco G, Pagani F, Maggi L, Scianni M, Panzanelli P, Giustetto M, Ferreira TA et al (2011) Synaptic pruning by microglia is necessary for normal brain development. Science 333(6048):1456-1458. https://doi.org/10.1126/science.1202529

26. Schafer DP, Lehrman EK, Kautzman AG, Koyama R, Mardinly AR, Yamasaki R, Ransohoff RM, Greenberg ME et al (2012) Microglia sculpt postnatal neural circuits in an activity and complement-dependent manner. Neuron 74(4):691-705. https://doi. org/10.1016/j.neuron.2012.03.026

27. Scheff SW, Price DA, Schmitt FA, Mufson EJ (2006) Hippocampal synaptic loss in early Alzheimer's disease and mild cognitive impairment. Neurobiol Aging 27(10):1372-1384. https://doi.org/ 10.1016/j.neurobiolaging.2005.09.012

28. Hong S, Beja-Glasser VF, Nfonoyim BM, Frouin A, Li S, Ramakrishnan S, Merry KM, Shi Q et al (2016) Complement and microglia mediate early synapse loss in Alzheimer mouse models. Science 352(6286):712-716. https://doi.org/10.1126/science. aad 8373

29. Dejanovic B, Huntley MA, De Mazière A, Meilandt WJ, Wu T, Srinivasan K, Jiang Z, Gandham V et al (2018) Changes in the synaptic proteome in tauopathy and rescue of tau-induced synapse loss by C1q antibodies. Neuron 100(6):1322-1336. https://doi. org/10.1016/j.neuron.2018.10.014

30. Michailidou I, Willems JG, Kooi EJ, van Eden C, Gold SM, Geurts JJ, Baas F, Huitinga I et al (2015) Complement C1q-C3-associated synaptic changes in multiple sclerosis hippocampus. Ann Neurol 77(6):1007-1026. https://doi.org/10.1002/ana.24398

31. Watkins LM, Neal JW, Loveless S, Michailidou I, Ramaglia V, Rees MI, Reynolds R, Robertson NP et al (2016) Complement is activated in progressive multiple sclerosis cortical grey matter lesions. J Neuroinflamm 13(1):1-13. https://doi.org/10.1186/ s12974-016-0611-x

32. Sellgren CM, Gracias J, Watmuff B, Biag JD, Thanos JM, Whittredge PB, Fu T, Worringer K et al (2019) Increased synapse elimination by microglia in schizophrenia patient-derived models of synaptic pruning. Nature Neurosci 22(3):374-385. https://doi. org/10.1038/s41593-018-0334-7

33. Comer AL, Jinadasa T, Sriram B, Phadke RA, Kretsge LN, Nguyen TPH, Antognetti G, Gilbert JP et al (2020) Increased expression of schizophrenia-associated gene $\mathrm{C} 4$ leads to hypoconnectivity of prefrontal cortex and reduced social interaction. PLoS Biol 18(1):e3000604. https://doi.org/10.1371/journal.pbio.30006 04

34. Botto M, Dell'Agnola C, Bygrave AE, Thompson EM, Cook HT, Petry F, Loos M, Pandolfi PP et al (1998) Homozygous C1q deficiency causes glomerulonephritis associated with multiple apoptotic bodies. Nature Genet 19(1):56-59. https://doi.org/10.1038/ ng0598-56

35. Wessels MR, Butko P, Ma M, Warren HB, Lage AL, Carroll MC (1995) Studies of group B streptococcal infection in mice deficient in complement component $\mathrm{C} 3$ or $\mathrm{C} 4$ demonstrate an essential role for complement in both innate and acquired immunity. Proc Natl Acad Sci U S A 92(25):11490-11494. https://doi.org/10.1073/ pnas.92.25.11490

36. Ruseva MM, Hughes TR, Donev RM, Sivasankar B, Pickering MC, Wu X, Harris CL, Morgan BP (2009) Crry deficiency in complement sufficient mice: $\mathrm{C} 3$ consumption occurs without associated renal injury. Mol Immunol 46(5):803-811. https://doi.org/ 10.1016/j.molimm.2008.09.003

37. Saito T, Matsuba Y, Mihira N, Takano J, Nilsson P, Itohara S, Iwata N, Saido TC (2014) Single app knock-in mouse models of Alzheimer's disease. Nature Neurosci 17(5):661-663. https://doi. org/10.1038/nn.3697

38. Oddo S, Caccamo A, Shepherd JD, Murphy MP, Golde TE, Kayed R, Metherate R, Mattson MP et al (2003) Triple-transgenic model of Alzheimer's disease with plaques and tangles: Intracellular 
Abeta and synaptic dysfunction. Neuron 39(3):409-421. https:// doi.org/10.1016/s0896-6273(03)00434-3

39. Wing MG, Seilly DJ, Bridgman DJ, Harrison RA (1993) Rapid isolation and biochemical characterization of rat $\mathrm{C} 1$ and $\mathrm{C} 1 \mathrm{q} . \mathrm{Mol}$ Immunol 30(5):433-440. https://doi.org/10.1016/0161-5890(93) 90111-N

40. Györffy BA, Kun J, Török G, Bulyáki É, Borhegyi Z, Gulyássy P, Kis V, Szocsics P et al (2018) Local apoptotic-like mechanisms underlie complement mediated synaptic pruning. Proc Natl Acad Sci U S A 115(24):6303-6308. https://doi.org/10.1073/pnas. 1722613115

41. Harris CL, Lublin DM, Morgan BP (2002) Efficient generation of monoclonal antibodies for specific protein domains using recombinant immunoglobulin fusion proteins: Pitfalls and solutions. J Immunol Methods 268(2):245-258. https://doi.org/10.1016/ S0022-1759(02)00207-7

42. Zelek WM, Harris CL, Morgan BP (2018) Extracting the barbs from complement assays: Identification and optimisation of a safe substitute for traditional buffers. Immunobiol 223(12):744-749. https://doi.org/10.1016/j.imbio.2018.07.016

43. Zelek WM, Taylor PR, Morgan BP (2019) Development and characterization of novel anti-C5 monoclonal antibodies capable of inhibiting complement in multiple species. Immunology 157(4):283-295. https://doi.org/10.1111/imm.13083

44. Reed GF, Lynn F, Meade BD (2002) Use of coefficient of variation in assessing variability of quantitative assays. Clin Diag Lab Immunol 9(6):1235-1239. https://doi.org/10.1128/CDLI.9.6.1235

45. Andreasson U, Perret-Liaudet A, van Waalwijk van Doorn LJ, Blennow K, Chiasserini D, Engelborghs S, Fladby T, Genc S et al (2015) A practical guide to immunoassay method validation. Front Neurol 6(179):1-8. https://doi.org/10.3389/fneur.2015.00179

46. Hanneman SK, Cox CD, Green KE, Kang DH (2011) Estimating intra- and inter-assay variability in salivary cortisol. Biol Res Nurs 13(3):243-250. https://doi.org/10.1177/1099800411404061

47. Sandholm K, Persson B, Skattum L, Eggertsen G, Nyman D, Gunnarsson I, Svenungson E, Nilsson B et al (2019) Evaluation of a novel immunoassay for quantification of $\mathrm{C} 1 \mathrm{q}$ for clinical diagnostic use. Front Immunol 10:7. https://doi.org/10.3389/fimmu.2019. 00007

48. Barthet G, Mulle C (2020) Presynaptic failure in Alzheimer's disease. Prog Neurobiol. Nov;194:101801. https://doi.org/10.1016/j. pneurobio.2020.101801

49. Cortes-Hernandez J, Fossati-Jimack L, Petry F, Loos M, Izui S, Walport MJ, Cook HT, Botto M (2004) Restoration of C1q levels by bone marrow transplantation attenuates autoimmune disease associated with $\mathrm{C} 1 \mathrm{q}$ deficiency in mice. Eur J Immunol 34(12):3713-3722. https://doi.org/10.1002/eji.200425616

50. Yabumoto C, Akazawa H, Yamamoto R, Yano M, Kudo-Sakamoto Y, Sumida T, Kamo T, Yagi H et al (2015) Angiotensin II receptor blockade promotes repair of skeletal muscle through downregulation of aging-promoting C1q expression. Sci Rep 5:14453. https://doi.org/10.1038/srep14453

51. Stephan AH, Madison DV, Mateos JM, Fraser DA, Lovelett EA, Coutellier L, Kim L, Tsai HH et al (2013) A dramatic increase of $\mathrm{C} 1 \mathrm{q}$ protein in the CNS during normal aging. J Neurosci 33(33):13460-13474. https://doi.org/10.1523/JNEUROSCI.133313.2013

52. Fonseca MI, Chu SH, Hernandez MX, Fang MJ, Modarresi L, Selvan P, MacGregor GR, Tenner AJ (2017) Cell-specific deletion of C1qa identifies microglia as the dominant source of $\mathrm{C} 1 \mathrm{q}$ in mouse brain. J Neuroinflamm 14(1):1-15. https://doi.org/10. 1186/s12974-017-0814-9

53. Naito AT, Sumida T, Nomura S, Liu ML, Higo T, Nakagawa A, Okada K, Sakai T et al (2012) Complement C1q activates canonical Wnt signaling and promotes aging-related phenotypes. Cell 149(6):1298-1313. https://doi.org/10.1016/j.cell.2012.03.047

54. Yonemasu K, Kitajima H, Tanabe S, Ochi T, Shinkai H (1978) Effect of age on $\mathrm{C} 1 \mathrm{q}$ and $\mathrm{C} 3$ levels in human serum and their presence in colostrum. Immunology 35(3):523-530. https://doi. org/10.1093/clind/15.6.1049

55. Watanabe S, Sato K, Hasegawa N, Kurihara T, Matsutani K, Sanada K, Hamaoka T, Fujita S et al (2015) Serum C1q as a novel biomarker of sarcopenia in older adults. FASEB J 29(3):10031010. https://doi.org/10.1096/fj.14-262154

56. Smyth MD, Cribbs DH, Tenner AJ, Shankle WR, Dick M, Kesslak JP, Cotman CW (1994) Decreased levels of C1q in cerebrospinal fluid of living Alzheimer patients correlate with disease state. Neurobiol Aging 15(5):609-614. https://doi.org/10.1016/01974580(94)00055-7

57. Pekkarinen PT, Heikkilä N, Kisand K, Peterson P, Botto M, Daha MR, Drouet C, Isaac L et al (2015) Dysregulation of adaptive immune responses in complement C3-deficient patients. Eur J Immunol 45(3):915-921. https://doi.org/10.1002/eji.201444948

58. Scott D, Botto M (2016) The paradoxical roles of C1q and C3 in autoimmunity. Immunobiol 221(6):719-725. https://doi.org/10. 1016/j.imbio.2015.05.001

59. Cole DS, Morgan BP (2003) Beyond lysis: How complement influences cell fate. Clin Sci 104(5):455-466. https://doi.org/10. 1042/CS20020362

60. Reichwald J, Danner S, Wiederhold KH, Staufenbiel M (2009) Expression of complement system components during aging and amyloid deposition in APP transgenic mice. J Neuroinflamm 6(35):1-12. https://doi.org/10.1186/1742-2094-6-35

61. Chen WT, Lu A, Craessaerts K, Pavie B, Sala Frigerio C, Corthout N, Qian X, Laláková J et al (2020) Spatial transcriptomics and in situ sequencing to study Alzheimer's disease. Cell 182(4):976991. https://doi.org/10.1016/j.cell.2020.06.038

62. Benoit ME, Hernandez MX, Dinh ML, Benavente F, Vasquez O, Tenner AJ et al (2013) C1q-induced LRP1B and GPR6 proteins expressed early in Alzheimer disease mouse models are essential for the $\mathrm{C} 1 \mathrm{q}$-mediated protection against amyloid- $\beta$ neurotoxicity. J Biol Chem 288(1):654-665. https://doi.org/10.1074/jbc.M112. 400168

63. Afagh A, Cummings BJ, Cribbs DH, Cotman CW, Tenner AJ (1996) Localization and cell association of C1q in Alzheimer's disease brain. Exp Neurol 138(1):22-32. https://doi.org/10.1006/ exnr.1996.0043

64. Veerhuis R, van der Valk P, Janssen I, Zhan SS, Van Nostrand WE, Eikelenboom P (1995) Complement activation in amyloid plaques in Alzheimer's disease brains does not proceed further than C3. Virch Archiv 426(6):603-610. https://doi.org/10.1007/ BF00192116

65. Thielens NM, Tedesco F, Bohlson SS, Gaboriaud C, Tenner AJ (2017) C1q: A fresh look upon an old molecule. Mol Immunol 89:73-83. https://doi.org/10.1016/j.molimm.2017.05.025

Publisher's Note Springer Nature remains neutral with regard to jurisdictional claims in published maps and institutional affiliations. 